\title{
EFEK ANTIBAKTERI EKSTRAK ETANOL DAUN AFRIKA (VERNONIA AMYGDALINA) SEBAGAI BAHAN ALTERNATIF MEDIKAMEN SALURAN AKAR TERHADAP PORPHYROMONAS GINGIVALIS
}

\author{
(ANTIBACTERIAL EFFECT OF ETHANOL EXTRACT OF AFRICA LEAF (VERNONIA \\ AMYGDALINA) AS AN ALTERNATIVE ROOT CANAL MEDICAMENT \\ ON PORPHYROMONAS GINGIVALIS)
}

\author{
Cut Nurliza, Fitri Yunita Batubara, Tiurma Sitompul \\ Departemen Konservasi Gigi \\ Fakultas Kedokteran Gigi, Universitas Sumatera Utara \\ Jl. Alumni No.2 Kampus USU Medan 20155
}

\begin{abstract}
Root canal treatment requires medicament intracanal material to eliminate microorganisms that can not be achieved by chemo-mechanical preparation techniques. One of the bacteria is often found in primary endodontic infections is Porphyromonas gingivalis. Africa leaf (Vernonia amygdalina) is a natural substance that has an antibacterial and can be used as an alternative material medicament root canal. The purpose of this experimental laboratory study was to determine the antibacterial effect of the ethanol extract of Africa leaf against Porphyromonas gingivalis. Two kg Africa leaves were extracted with $70 \%$ ethanol into viscous extract and diluting ethanol extract of Africa leaf in Mueller Hinton Broth starting from a concentration of 100, 50, 25, 12.5, 6.25 , and $3.125 \%$ were replicated 4 times. One $\mathrm{ml}$ of each concentration was added $1 \mathrm{ml}$ bacterial suspension, vortexed, and incubated at $37^{\circ} \mathrm{C}$ for 24 hours in the $\mathrm{CO}_{2}$ incubator, then compared with a control Mc Farland visually to determine Minimum Inhibitory Consentration (MIC). Then followed by counting the number of bacterial colonies Drop Plate Milles Misra method to determine Minimum Bactericidal Consentration (MBC) is taken for every $50 \mu \mathrm{L}$ concentration, dripped into Mueller Hinton Agar, replicated four times, then incubated at $37^{\circ} \mathrm{C}$ for 24 hours. In conclusion, ethanol extract of Africa leaf has an antibacterial effect on Porphyromonas gingivalis with MBC 50\% and MIC is not representative so the result is unknown.
\end{abstract}

Key words: medicament intracanal, Africa leaf, Porphyromonas gingivalis, antibacterial

\begin{abstract}
Abstrak
Perawatan saluran akar memerlukan bahan medikamen saluran akar untuk mengeliminasi mikroorganisme yang tidak dapat dicapai dengan teknik preparasi chemo-mechanical. Salah satu bakteri yang sering ditemukan pada infeksi endodontik primer adalah Porphyromonas gingivalis. Daun Afrika (Vernonia amygdalina) merupakan salah satu bahan alami yang bersifat antibakteri yang dapat dijadikan sebagai bahan alternatif medikamen saluran akar. Tujuan penelitian eksperimental laboratoris ini adalah untuk mengetahui efek antibakteri ekstrak etanol daun Afrika terhadap bakteri Porphyromonas gingivalis. Penelitian ini dimulai dengan melakukan ekstraksi daun Afrika sebanyak $2 \mathrm{~kg}$ dengan pelarut etanol 70\% hingga diperoleh ekstrak kental. Pengujian efek antibakteri menggunakan metode dilusi dengan mengencerkan ekstrak etanol daun Afrika dalam media MHB dimulai dari konsentrasi 100, 50, 25, 12,5, 6,25, dan 3,125\% yang direplikasi 4 kali. Setiap konsentrasi ditambahkan $1 \mathrm{ml}$ suspensi bakteri, divorteks, dan diinkubasi $37^{\circ} \mathrm{C}$ selama 24 jam pada inkubator $\mathrm{CO}_{2} \mathrm{kemudian}$ kekeruhan diamati dan dibandingkan dengan kontrol Mc Farland secara visual untuk menentukan nilai KHM. Kemudian dilanjutkan penghitungan jumlah koloni bakteri dengan metode Drop Plate Milles Misra untuk menentukan KBM yaitu setiap konsentrasi diambil $50 \mu$, diteteskan ke media MHA, direplikasi 4 petri, kemudian diinkubasi $37^{\circ} \mathrm{C}$ selama 24 jam. Sebagai kesimpulan, ekstrak etanol daun Afrika memiliki efek antibakteri terhadap Porphyromonas gingivalis secara in vitro dengan nilai KBM pada konsentrasi $50 \%$ dan nilai KHM tidak representatif sehingga tidak dapat diketahui hasilnya.
\end{abstract}

Kata kunci: medikamen saluran akar, daun Afrika, Porphyromonas gingivalis, antibakteri 
